\title{
Aktuální situace v oblasti IFRS
}

\section{Vážení čtenáři,}

na první pohled by se mohlo zdát, že tvorba a implementace IFRS je již vyřešený problém, který není třeba dále rozvádět. Opak je však pravdou. IFRS řeší z několika důvodů velmi intenzivní problémy, kvůli kterým je vhodné se o tuto problematiku zajímat. Rád bych se zastavil u hlavních témat, které považuji aktuálně za nejdůležitější

\section{Novely standardů a interpretací}

IFRS nejsou statické a intenzivně se mění. IASB má trvale rozpracovánu řadu projektů, které jsou krátkodobé dílčí povahy, ale i dlouhodobé koncepční povahy a zasahují podstatu řešení i více standardů najednou. Jejich kompletní přehled včetně harmonogramu jejich řešení a souvisejících diskusních materiálů, zveřejněných návrhů textů standardů, či jejich interpretací a obdržených připomínek najdete na oficiálních stránkách IASB. V této souvislosti bych chtěl zmínit především dva projekty, které v poslední době dospěly do závěrečné fáze: vykazování výnosů a leasingy. Výsledkem řešení těchto projektů je návrh nového standardu zabývajícího se výnosy ze smluv se zákazníky a novela standardu zabývajícího se leasingy. Podstatou standardu o výnosech ze smluv se zákazníky je sjednocení přístupů při uznávání výnosů, které byly dosud nejednotně ve standardu IAS 18 a ve standardu IAS 11. V případě IAS 17 spočívá zásadní změna v tom, že se přestane formálně odlišovat finanční a operativní leasing a ve výkazech nájemců se bude vykazovat jakákoliv forma nájmu aktiva vždy, a to jednotným způsobem. Obě zmiňované novely zasáhnou prakticky každou účetní jednotku a představují významnou změnu dosavadního způsobu vykazování v daných oblastech.

\section{Konvergence IFRS a US GAAP}

Cílem IFRS je, aby se staly globálními účetními standardy. K jeho dosažení zbývá dořešit využívání IFRS v USA, které dosud používají svůj národní systém účetních standardů označovaný jako US GAAP. Zájem o sblížení obou systémů je oboustranný a již od roku 2002 intenzivně probíhá a projevil se řadou novel standardů, či společnými projekty tvorby nových standardi̊ v obou systémech. Přesto, že stále přetrvávají rozdíly, které budou vyžadovat řešení, dospěla konvergence do takového stádia, že USA zvažují přechod na IFRS jako na svůj národní systém regulace účetnictví pro domácí společnosti. Konečné rozhodnutí v této oblasti bude náležet US SEC, která opakovaně potvrdila, že toto rozhodnutí provede v roce 2011, avšak nepředjímá, jaké toto rozhodnutí bude. US SEC si tím vyhrazuje právo posuzovat do roku 2010 směr, kterým se IFRS ubírají, jejich kvalitu, vzájemnou konvergenci a také nezávislost, transparentnost a stabilitu řízení a financování IASB, která je za tvorbu IFRS odpovědná.

\section{Správa IASB}

Jak jsem již výše zmínil, je důležitou podmínkou pro další rozvoj IFRS i financování a řízení samotného IASB, které by mělo garantovat, stabilitu, transparentnost a nezávislost tohoto orgánu. Uvedené charakteristiky jsou pečlivě sledovány všemi zainteresovanými 
stranami a jejich ohrožení by mohlo znamenat ohrožení pozice IFRS v budoucnosti. Z uvedených důvodů patřila $\mathrm{k}$ významné události volby nového předsedy IASB. Dlouhou dobu zastával tuto funkci sir David Tweedie, kterému končí funkční období v souladu se stanovami Nadace IFRS. Sir David Tweedie patří k velkým osobnostem v oblasti IFRS, kterému se přičítá zásadní zásluha o rozvoj IFRS a s velkou pozorností bylo sledováno, kdo bude zvolen jako jeho nástupce, kterým byl pro nové funkční období zvolen Hans Hoogervorst. Jedná se o významnou osobnost, která je však všeobecně považována spíše za politika (zastával řadu funkcí v nizozemské vládě), který nemá formální vzdělání ani dlouhodobou praxi voblasti účetnictví. Logicky byl tedy $\mathrm{k}$ tomuto předsedovi hledán místopředseda, který by naopak doplňoval Hanse Hoogervorsta zkušenostmi z oblasti účetního výkaznictví, a tím se stal Ian Mackintosh, který má rozsáhlé a dlouhodobé zkušenosti z práce $\mathrm{v}$ profesních organizacích účetních a auditorů, a to v mezinárodním měřítku. Kombinace těchto dvou osobností je obecně přijímána pozitivně a měla by zabezpečit jak prosazení IFRS v rovině politické, tak jejich odbornou kvalitu z hlediska technického.

\section{Implementace IFRS a audit závěrek podle IFRS}

Samostatnou kapitolou je implementace IFRS do národních úprav účetnictví, úroveň plnění požadavků IFRS při sestavování účetních závěrek v jednotlivých státech a také kvalita auditu takových závěrek ze strany auditorů. $\mathrm{Z}$ tohoto hlediska bych rád zmínil dvě důležité skutečnosti. První je novela zákona o účetnictví, kterou právě projednala Poslanecká sněmovna Parlamentu ČR a předala ji Senátu. Tato novela, mimo jiné, rozšiřuje okruh účetních jednotek, které účtují a sestavují účetní závěrku podle IFRS. Jedná se o dvě důležité situace, na které se novela vztahuje: případ, kdy účetní jednotka prrestává být emitentem cenných papírů pouze dočasně a je předpoklad, že se jím opět po čase stane a případ, kdy je účetní jednotka součástí konsolidačního celku, za který je mateřskou společností sestavována konsolidovaná účetní závěrka v souladu s IFRS. Obě situace jsou účetními jednotkami očekávány a pozitivní vlastností zmiňované novely je to, že účetním jednotkám nenařizuje konkrétní volbu účetního systému, ale dává jim možnost volby mezi IFRS a účtováním podle českých účetních předpisů. Druhým tématem, které jsem zmínil, je kvalita auditu závěrek sestavených podle IFRS, kterým se začala zabývat i Komora auditorů ČR svojí analýzou kterou provedl výbor pro IFRS ve spolupráci s oddělením metodiky na základě požadavku Výkonného výboru KAČR. Tato analýza nepřinesla př́liš potěšující informace o kvalitě závěrek podle IFRS v ČR, úrovni jejich zveřejňování, ani kvalitě jejich audiu a odhalila řadu konkrétních nedostatků. Obecné shrnutí prvních výsledků této analýzy bylo zveřejněno v čísle 9 časopisu Auditor vydávaného Komorou auditorů ČR.

Na závěr bych se chtěl zmínit o důležité skutečnosti, která se týká tohoto čísla Českého finančního a účetního časopisu a zejména pak článků v něm. Podstatná část článků zařazených do tohoto čísla je monotématicky zaměřena na problematiku fúzí a podnikových kombinací se specifickým zaměřením na přeshraniční fúze. Tyto články jsou výsledkem řešení projektu GAČR „Komparativní analýza národních účetních a daňových regulačních systémů EU s důrazem na přeshraniční fúze“ (registrační číslo GAČR P403/10/1982). Řada z nich byla také prezentována 5. listopadu 2010 na workshopu „Přeshraniční fúze - účetní a daňové souvislosti“, který byl pořádán na katedře finančního účetnictví a auditingu VŠE v Praze jako prezentace výsledků řešení zmiňovaného projektu. Druhou část těchto článků najdete v prvním čísle ČFÚČ v roce 2011. 
PŘEDMLUVA - Mejzlík, L.: Aktuální situace v oblasti IFRS..

Věřím, že si každý $\mathrm{z}$ vás najde $\mathrm{v}$ tomto čísle časopisu užitečné informace, které, které budou přínosem nebo inspirací pro jeho vědecko-výzkumnou činnost a protože toto číslo již bude vycházet v době příprav na vánoční a novoroční svátky, přeji vám všem jejich př́ijemné strávení a klidný start do nového roku.

doc. Ing. Ladislav Mejzlík, Ph.D.

vedoucí Katedry finančního účetnictví a auditingu

Fakulty financí a účetnictví

Vysoké školy ekonomické v Praze 